石油技術協会誌 第 82 巻 第 5 号 （平成 29 年 9 月） $346 \sim 354$ 頁 Journal of the Japanese Association for Petroleum Technology Vol. 82, No. 5 (Sept., 2017) pp. 346 354

\begin{tabular}{l}
\hline 講 演 \\
Lecture \\
\hline
\end{tabular}

\title{
海洋掘削リグの進化と今後の展望*
}

\author{
前田啓 彰**
}

(Received July 6, 2017 ; accepted August 10, 2017)

\section{The technological history of offshore drilling rigs and the outlook of the future}

\author{
Hiroaki Maeda
}

Abstract : There are three types of offshore drilling rigs: Drillship, Semi-submersible, Jack-up rig.

As the generation of rig progressed, the operating water depth had deepened and consequently the ability of drilling equipment, redundancy and on-board capacity, had been enhanced.

The technological evolution of drilling rig made the hull and drilling equipment greater in size, which enabled deeper operation and that also led to considerable improvement in performance of major drilling equipment.

Looking back the progress of element technology in the past, we'll look into the latest specifications as of now and predict the rig of the future.

Keywords : deepwater, deepwater rig, Semi-submersible rig, Drillship, design, Jack-up rig, development

\section{1.はじめに}

海洋掘削リグには大きく分けて, ドリルシップ, セミサ ブリグ，ジャッキアップリグと 3 種類のタイプがあるが, 世代の進化とともに稼働水深が大きくなり，それに伴って 掘削機器の能力・壳長性の強化, 搭載能力の大型化などが 進んできた。建造年別でリグ数の推移を見ると, 原油価格 に伴って変動するという相関関係がある（図 1)。1973 年 頃から始まつた原油価格の上昇に合わせ, リグ建造の第一 次ブームがあった。また 2000 年以降, さらなる原油価格 の高騰に伴い, かつてないリグ建造ラッシュを経てリグ数 も増え続けてきた。一方, ここ数年は, 原油価格下落に伴 い古いタイプのリグはその寿命を迎え，次第にマーケット から退出しつつある。IHS-Petrodataによると 2017 年 5 月 現在, ドリルシップ 119 基, セミサブリグ 163 基, ジャッ キアップリグ 540 基の合計 822 基が存在する。

\section{2. 海洋掘削リグの歴史}

\section{1 海洋掘削事始め}

19 世紀末, 海外では米国カリフォルニア州サンタバー

* 平成 29 年 6 月 14 日, 平成 29 年度石油技術協会春季講演会作井部門 シンポジウム「時代の流れと作井技術の変遷一作井技術の過去, 現在, そして将来の見通し」にて講演 This paper was presented at the 2017 JAPT Drilling Symposium entitled "Evolution of drilling technologies over time - Drilling technologies in the past, present and future vision" held in Tokyo, Japan, June 14, 2017

** 日本海洋掘削(森)プロジェクトエンジニアリング部Ｐroject Engineering Department, Japan Drilling Co., Ltd.
バラのサマーランドで, 海岸に栈橋をかけて, 陸上で使っ ていた櫓を立てて掘削したのが海洋掘削のはじまりとされ る。日本国内では, 同時期に新潟県出雲崎海岸の尼瀬で 30〜 $50 \mathrm{~m}$ ほど沖合いに向かって栈橋をかけ, 掘削が開始 された。1920 年代には物理探査の結果, テキサス州やル イジアナ州のメキシコ湾岸に多数の岩塩ドームが確認され たこともあり, 多数の石油企業がこの地域に誕生した。そ の後, 1930 年頃までは米国を中心に海洋での掘削が行わ れたが, 栈橋や波止場の岸壁などの上からの掘削が主流で あった。

\subsection{Gilliasso（1933 年）}

1930 年代に入ると世界で初めてとなる移動式掘削装置 が誕生する。1933 年に湖沼用着底型掘削リグとしてペン シルバニア州の造船所にて完成し, “Gilliasso”と命名され た（図 2)。本リグ Gilliasso は船底にタンクを備え, 掘削 時にはタンクに水を張ることで着底して掘削を実施し, 移 動時にはタンクの水を抜いて浮遊するという方法が取られ た。本リグの完成は確かに時代の大きな一歩であったが, 海象条件の厳しいところでの移動式掘削リグの実用化には まだ時間を要した。

2.3 着底型掘削リグからジャッキアップリグヘ

海洋での移動式掘削リグは, 1949 年に Brenton Rig 20 が 最初となる（図 3)。型式は Gilliasso と同じく着底型掘削 リグであった。その後 1963 年まで海洋での着底型掘削リ グは大型化し, 水深も $45 \mathrm{ft}(13.7 \mathrm{~m})$ までは稼働可能になっ た。しかし, 着底型掘削リグは船底のポンツーンと作業デッ 


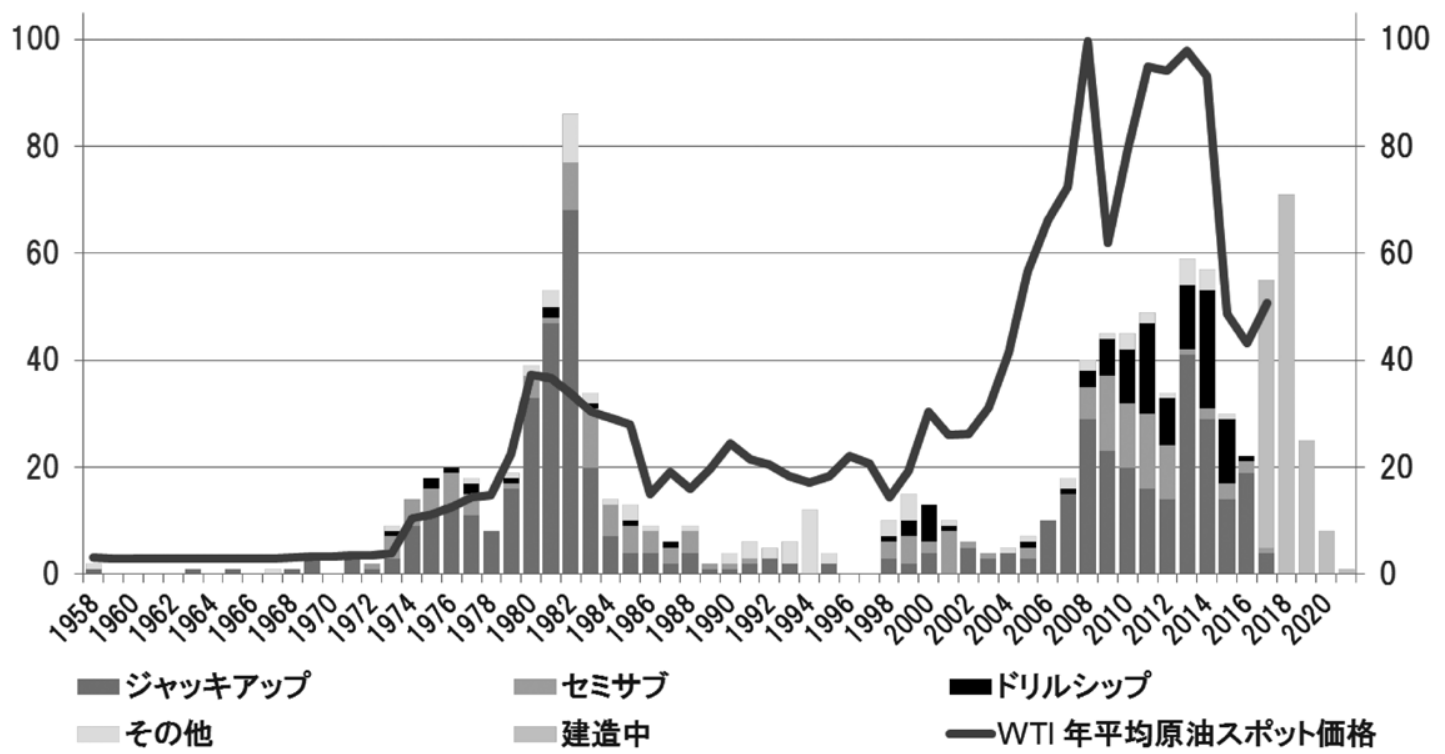

図 1 建造年別リグ推移と原油価格の推移

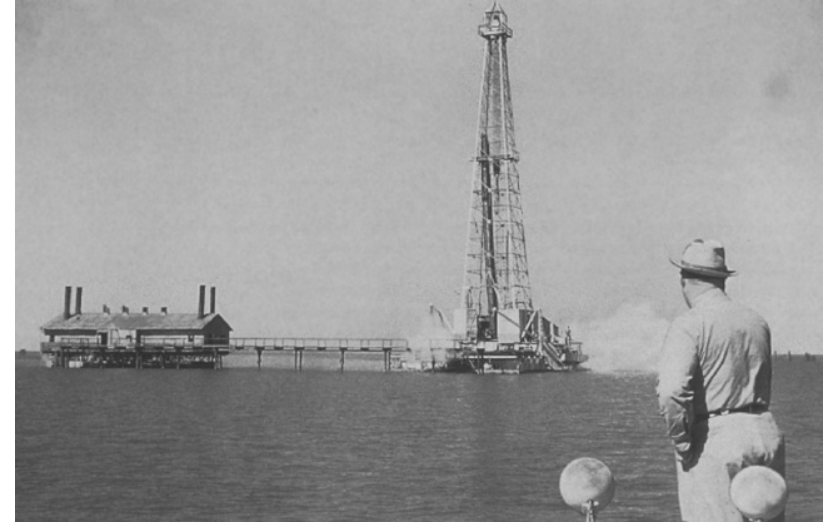

図 2 Gilliasso

原典 : Texaco (Chevron) 出所 : Pioneering Offshore : The Early Years

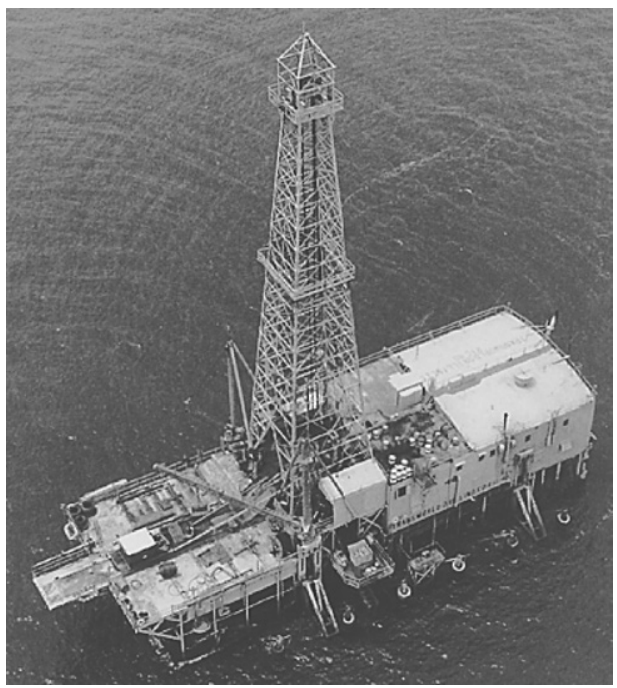

図 3 Brenton Rig 20

原典：Offshore Data Service 出所 : Pioneering Offshore : The Early Years

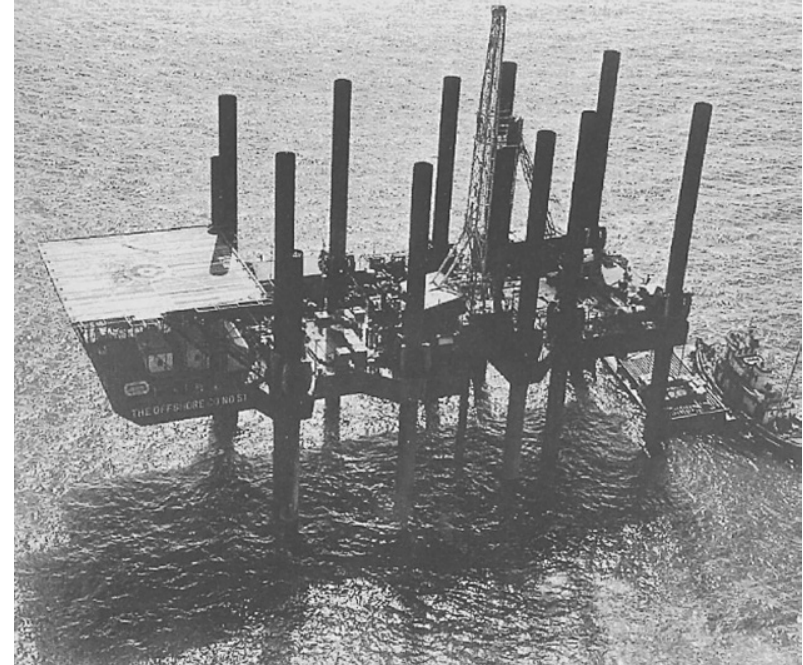

図 4 Rig No.51

原典 : Transocean 出所 : Pioneering Offshore: The Early Years

キとの間隔が固定されており，作業時と曳航時の復原力が 不十分であった。このような状況の下, 当時の設計者たち は水深が深いところにも着底でき，しかもデッキの高さを 変えることができる掘削リグの開発に尽力した。1954 年, 世界初となる甲板昇降型掘削リグ（以下ジャッキアップリ グ）Rig No.51 が完成した（図 4)。長さ $48.8 \mathrm{~m}$ の Leg が 12 本も搭載されており，エアージャッキで昇降した。しかし ながら, Leg 本数が 12 本もあることで, 作業性および移 動性には課題を抱えていた。

\subsection{Zapata Scorpion（1956 年）}

1950 年代, 土木の重機や鉱山機器の会社の社長であっ た Robert LeTourneau 氏が現在の 3 本脚のジャッキアップ リグのデザインを初めて開発した。特徴は, 全天候型のプ ラットフォームであり, 浮上させて迅速に移動させるこ とができ，またトラス構造のレグを搭載していることで 
あった。当時は大きな反響を呼んだデザインであったが, 約 300 万ドルの船価に加え実績のないデザインを採用す る会社はごこにもなかった。LeTourneau 氏は，Zapata Offshore 社に本デザインを提案する。Zapata Offshore 社の社 長は, その後アメリカ合衆国第 41 代大統領となる George H.W.Bush 氏であった。Bush 氏はその後のインタビューで LeTourneau 氏のことをこう評している。「彼はこんな提案 を持ってZapataへやって来た。彼が自腹でリグを建造する。 Zapata が 40 万ドルを前払いして完工し，もしうまくいか なかったら払い戻す。でもうまくいったら，さらに55 万 ドルの増資と, Zapata の普通株 3 万 8 千株をいただくと。 これだけの自信を持っている男なら，一か八か賭けて夕て もいいと思った。」

Zapata Offshore 社は LeTourneau 社のデザインの採用を 決定し、1956 年に完成した。“Zapata Scorpion” と命名され， メキシコ湾での稼働を開始した（図 5)。同年 1 マイル間 のロケーションムーブで 8.5 時間という世界記録を樹立す る。今までにないロケーションムーブの早さは, $5 \sim 7$ feet （1.5～ $2.1 \mathrm{~m} ）$ という浅いペネトレーションでも安定して 稼働できることが要因であった。Zapata Scorpion が優秀な 作業性と移動性を示せたことで, LeTourneau 社のデザイ ンは現在のジャッキアップリグの原型となるとともに，世 界の主流デザインとなっていく。

\section{5 白竜号 (1958 年)}

日本国内においても, 1958 年には, LeTourneau 社のデ ザインを採用して, 石油資源開発株式会社が石川島播磨重 工業に発注した白竜号が秋田の海岸で建造された（図 6)。 当時, LeTourneau のデザインでは 8 号基目となるリグで あった。完成から 11 年間, 主に秋田・山形・新潟県の沖 合いで稼働し，51 坑の坑井を掘削した。1968 年, 日本海

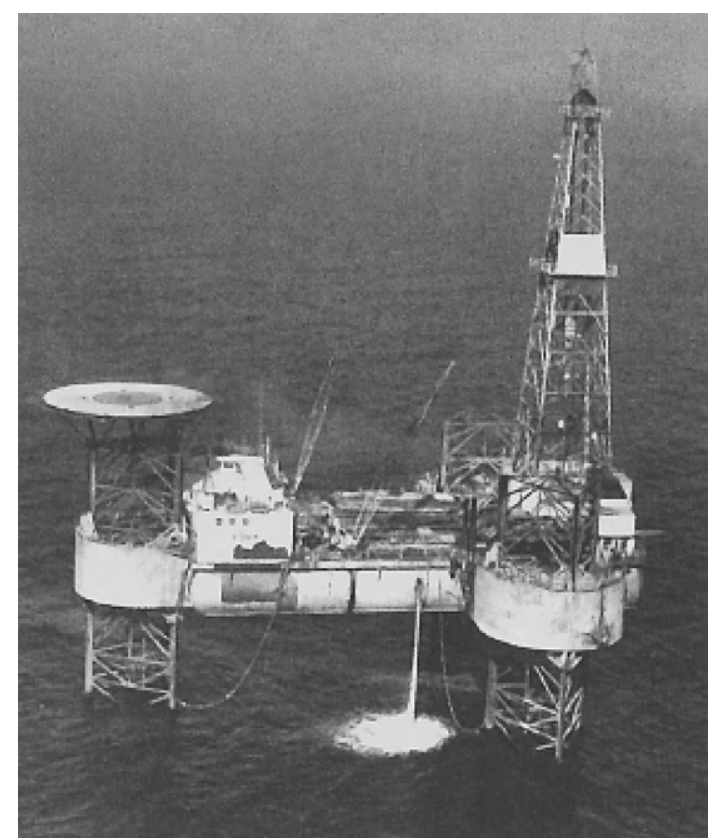

図 5 Zapata Scorpion

原典：Malcolm Sharples 出所 : Pioneering Offshore: The Early Years

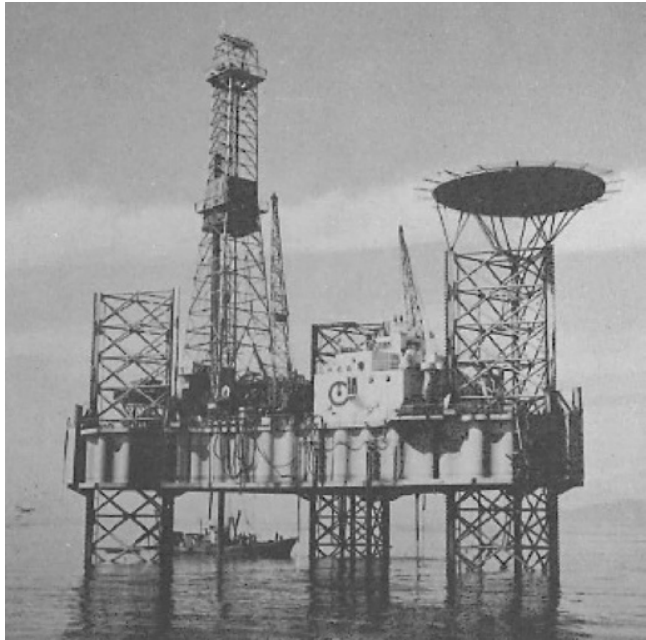

図 6 白竜号

出所：日本海洋掘削株式会社

洋掘削株式会社（以下，JDC）に売却され，第一白竜と船 名を変えた本船は, インドネシア海域, エジプトスエズ湾 で稼働し, 掘削リグの寿命は長くて 20 年と言われていた 中, 当時としては 28 年間という異例の長寿を保った。

\section{6 浮遊式リグ誕生の背景}

移動式掘削リグの登場により, 海洋での掘削は移動性も 作業性も向上したが, 当時の技術では水深 $60 \mathrm{~m}$ くらいま での稼働が限界であった。当時のオペレータ各社は海洋で の油層の広がりを水深 $600 \mathrm{ft} （ 182.9 \mathrm{~m} ）$ くらいのエリアま であると自信を持っており，探鉱・開発意欲は高まってい た。特に, メキシコ湾とともに海洋掘削が盛んであったカ リフォルニア海域は, 平坦な大陸棚部分が少なく, 急激に 水深が深くなることから着定式掘削リグで稼働できる海 域も限られた。また太平洋からの波とうねりがプラット フォームの設置を困難とし, 世界的にも風光明媚なところ で知られていたために，何をするにも環境規制を考慮しな ければならなかった。技術的にも，また高まる環境規制へ 対応することも含め, 課題が多い海域であった。

2.7 CUSS Group の誕生と実験船 Submarex(1953 年) そのような条件の下では, 移動式で水深の深い海域で も稼働可能な掘削リグ, すなわち浮遊式の掘削リグが待 望された。中古船を改造し, 陸上用の掘削設備を搭載し て掘削を試みることは行われていたが, 本格的な研究開 発は 1948 年にCUSS Group が結成されてからであった。 Continental, Union, Shell, Superior Oil の 4 社の頭文字をとつ た CUSS Group が協同で浮遊式リグの掘削技術について研 究・開発を開始した。当時から目標とされたものは, BOP を海底面に設置しライザーパイプを用いて泥水を循環し， 海象条件が悪くなった際には係留索や BOP をディスコネ クトし, またリエントリーも可能にするという, 現在にも つながる技術の開発であった。1953 年, 米国海軍の中古 船を改造して実験船とし, “Submarex” と命名され, デリッ クとサブストラクチヤは船体中央部左舷に張り出して設置 された。水深 $30 \sim 400 \mathrm{ft} （ 9.1 \sim 121.9 \mathrm{~m})$ でのコア採取に 


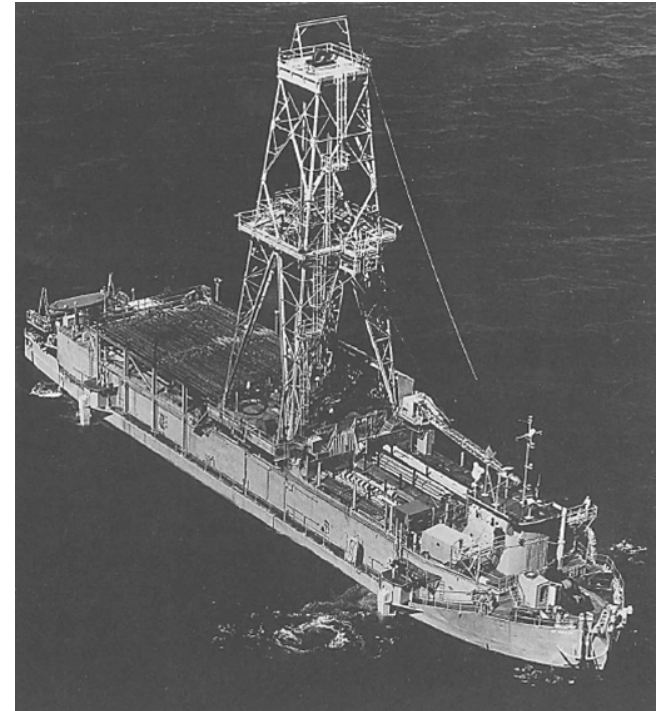

図 7 CUSS 1

原典 : GlobalSantaFe Corp. 出所 : Pioneering Offshore: The Early Years

大活躍した。

\subsection{CUSS 1（1956 年）}

CUSS Group は Submarex に引き続き, 同じく米国海軍 の中古船を改造し，CUSS 1 というドリルシップを完成さ せた（図 7)。本船の特徵としては, 上記 CUSS Group が 目標とした技術を採用した他，初めて船体中央部に掘削用 の開口部 “ムーンプール”が設けられた。船体動摇に対し ても安定して掘削作業が可能なように，デリックにガイド レールやトラベリングブロック，オートマチックパイプハ ンドリングなどが採用された。水深 $350 \mathrm{ft} （ 106.7 \mathrm{~m} ）$ まで のエリアで大いに活躍し，現在の浮遊式リグの祖を築いた と言える。

\section{9 半潜水型掘削リグ “Blue Water No.1"}

CUSS-1 以降もさまざまなドリルシップが開発され，進 化を続け現在の大型ドリルシップにつながっていく。だが, 当初は船体の全長も $100 \mathrm{~m}$ 以下であり，荒天時には船体 動摇が大きく，掘削作業が停滞することが多かつた。その ため，波浪中の動摇性能に優れたリグの開発が望まれた。 当時は Shell 社が中心となり, その後半潜水型掘削リグ（以 下，セミサブリグ） と呼ばれるようになる型式の掘削リグ を開発した。初代セミサブリグは “Blue Ocean No.1”であ り, 図 8 の写真を参照されたいが，同リグはすでに当時か

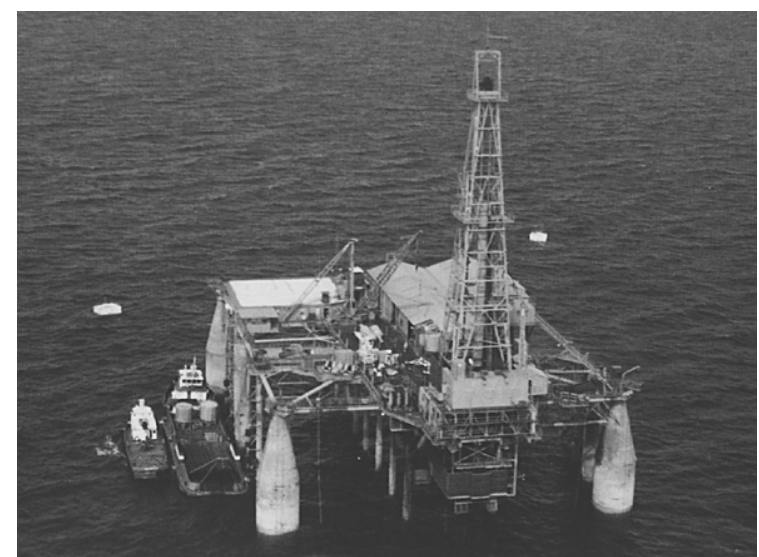

図 8 Blue Ocean No.1

原典：Bruce Collipp 出所 : Pioneering Offshore: The Early Years

ら現在のセミサブリグにつながる形をしており，荒天時に も安定した動摇性能を示したと記録にある。当時はライバ ル各社も強い関心を持ち, リグ上空から写真や動画を撮影 したと記録されている。海象条件が穏やかな日に搭乗した クルーは，浮遊していることに気づかなかったという逸話 もあり，セミサブリグの特性である動摇性能の優秀性を示 していたと言える。

その後, ジャッキアップリグ, ドリルシップ, セミサブ リグはそれぞれの型式ごとに進化を続けてきた。表 1 にそ れぞれの型式の第 1 号基と 2016 年にデリバリーされた最 新型の比較を試みた。船体も大型化し, 稼働エリアも拡大 している。掘削リグの進化は初代モデルからさまざまな要 素技術が発達したために, 現在の稼働水深や掘削深度を実 現することができたとも言える。その変遷は，リグのジェ ネレーションで確認することができる。

\section{3. 浮遊式リグのジェネレーション}

ドリルシップやセミサブリグは，そのリグが建造された 時期や仕様によってジェネレーション別に分類され，掘削 リグの進歩はジェネレーションの変遷にも表れている。 表 2,3 はドリルシップとセミサブリグのジェネレーショ ンを示したものである。リグのジェネレーションについて 統一的な定義があるわけではないが，米 BOEM(Bureau of Ocean Energy Management) や，世界最大の掘削コントラ クターである Transocean 社はおおむね表 2,3 のように分

表 1 第 1 号基と最新型リグの比較

\begin{tabular}{|l|c|c|c|c|c|c|}
\hline \multicolumn{1}{|c|}{ リグ型式 } & \multicolumn{2}{|c|}{ ジャッキアップリグ } & \multicolumn{2}{|c|}{ ドリルシップ } & \multicolumn{2}{c|}{ セミサブリグ } \\
\hline リグ名 & Zapata Scorpion & $\begin{array}{c}\text { Maersk } \\
\text { Invincible }\end{array}$ & CUSS-1 & $\begin{array}{c}\text { Deepwater } \\
\text { Conqueror }\end{array}$ & Blue Water No.1 & $\begin{array}{c}\text { Ocean } \\
\text { Greatwhite }\end{array}$ \\
\hline 建造年 & 1956 & 2016 & 1956 & 2016 & 1961 & 2016 \\
\hline 稼働水深 & $32 \mathrm{~m}$ & $152.4 \mathrm{~m}$ & $106.7 \mathrm{~m}$ & $3,600 \mathrm{~m}$ & $90 \mathrm{~m}$ & $3,000 \mathrm{~m}$ \\
\hline 全長 & $45.7 \mathrm{~m}$ & $104.8 \mathrm{~m}$ & $79.2 \mathrm{~m}$ & $238 \mathrm{~m}$ & $73.3 \mathrm{~m}$ & $122.5 \mathrm{~m}$ \\
\hline 全幅 & $24.4 \mathrm{~m}$ & $88.6 \mathrm{~m}$ & $26.8 \mathrm{~m}$ & $42 \mathrm{~m}$ & $61.5 \mathrm{~m}$ & $77.7 \mathrm{~m}$ \\
\hline
\end{tabular}


表 2 ドリルシップのジェネレーション変遷

\begin{tabular}{|c|c|c|c|c|c|c|}
\hline Generation & 1st \& 2nd & 3rd & 4 th & 5th & 6 th & 7 th \\
\hline Year & $\sim 1970 \mathrm{~s}$ & Early 1980s & Late 1980s to 1997 & 1997 to 2004 & 2005 to 2010 & $2010 \sim$ \\
\hline Water Depth & $<3,000 \mathrm{ft}$ & $<5,000 \mathrm{ft}$ & $<10,000 \mathrm{ft}$ & $10,000 \mathrm{ft}$ & $12,000 \mathrm{ft}$ & Over $12,000 \mathrm{ft}$ \\
\hline VDL & $>10,000$ ston & 10,000 ston & $>10,000$ ston & $<20,000$ ston & $>20,000$ ston & $>20,000 \mathrm{ston}$ \\
\hline Station Keeping & Chain Mooring & $\begin{array}{c}\text { Chain/Wire } \\
\text { Combination Mooring }\end{array}$ & $\begin{array}{c}\text { Chain/Wire } \\
\text { Combination Mooring }\end{array}$ & $\begin{array}{c}\text { DPS } \\
\text { Min class II }\end{array}$ & $\begin{array}{c}\text { DPS, } \\
\text { Min class II }\end{array}$ & $\begin{array}{c}\text { DPS, } \\
\text { Class III }\end{array}$ \\
\hline Hook Load & $<700$ ston & $<700$ ston & $<1,000$ ston & $<1,000$ ston & $<1,250$ ston & $>1,250$ ston \\
\hline Topdrive & No & Retrofit & Common & Common & Common & Common \\
\hline Load Path & Single & Single & Single & Single or Dual & Dual & Dual \\
\hline Pipe Handling & Manual & Manual & Automated & $\begin{array}{c}\text { Automated } \\
\text { Single/Dual }\end{array}$ & $\begin{array}{c}\text { Automated } \\
\text { Dual }\end{array}$ & $\begin{array}{c}\text { Automated } \\
\text { Dual }\end{array}$ \\
\hline BOP & $10,000 \mathrm{psi}$ & $10,000 \mathrm{psi}$ & $15,000 \mathrm{psi}$, & $\begin{array}{c}15,000 \mathrm{psi}, \\
5-\text { Rams }\end{array}$ & $\begin{array}{c}15,000 \mathrm{psi}, \\
6-\text { Rams }\end{array}$ & $\begin{array}{c}15,000 \mathrm{psi}, \\
7-\text { Rams }\end{array}$ \\
\hline BOP Control & Hydraulic & Hydraulic & MUX & MUX & MUX & MUX \\
\hline Mud Pump & $2 \times 1,600 \mathrm{hp}$ & $2 \times 1,600 \mathrm{hp}$ & $3 \times 1,600 \mathrm{hp}$ & $4 \times 2,200 \mathrm{hp}$ & $4 \times 2,200 \mathrm{hp}$ & Min $4 \times 2,200 \mathrm{hp}$ \\
\hline
\end{tabular}

表 3 セミサブリグのジェネレーションの変遷

\begin{tabular}{|c|c|c|c|c|c|c|}
\hline Generation & 1st \& 2nd & $3 r d$ & 4 th & 5 th & 6th & 7 th \\
\hline Year & Mid 1970s & Early 1980s & $\begin{array}{c}\text { Late } 1980 \text { s to Early } \\
1990 \text { s }\end{array}$ & $\begin{array}{l}\text { Late } 1990 \text { s to } \\
\text { Early } 2000 \text { s }\end{array}$ & $\begin{array}{l}\text { Late } 2000 \text { s to } \\
2010\end{array}$ & 2010- \\
\hline Water Depth & $1,000 \mathrm{ft}$ & $3,000 \mathrm{ft}$ & $5,000 \mathrm{ft}$ & $\begin{array}{l}7,500 \text { to } \\
10,000 \mathrm{ft}\end{array}$ & Over $10,000 \mathrm{ft}$ & Over $12,000 \mathrm{ft}$ \\
\hline VDL & 3,000 ston & 4,000 ston & 5,000 ston & 7,000 ston & 8,500 ston & 9,000 ston \\
\hline Station Keeping & Chain Mooring & $\begin{array}{c}\text { Chain/Wire } \\
\text { Combination Mooring }\end{array}$ & $\begin{array}{c}\text { Chain/Wire } \\
\text { Combination Mooring }\end{array}$ & DPS & $\begin{array}{l}\text { DPS, Self-pro- } \\
\text { pelled }\end{array}$ & $\begin{array}{l}\text { DPS, Self-pro- } \\
\text { pelled }\end{array}$ \\
\hline Hook Load & 500 ston & 650 ston & 750 ston & 1,000 ston & 1,250 ston & $>1,250$ ston \\
\hline Topdrive & No & Retrofit & Common & Common & Common & Common \\
\hline Load Path & Single & Single & Single & Single or Dual & Dual & Dual \\
\hline Pipe Handling & Manual & Manual & Automated & Automated & Automated & Automated \\
\hline $\mathrm{BOP}$ & $10,000 \mathrm{psi}$ & $10,000 \mathrm{psi}$ & 15000 psi, & $\begin{array}{l}\text { 15,000 psi, } \\
\text { 6-Rams }\end{array}$ & $\begin{array}{l}\text { 15,000 psi, } \\
\text { 6-Rams }\end{array}$ & $\begin{array}{l}\text { 15-20,000 psi, } \\
\text { 7-8 Rams }\end{array}$ \\
\hline BOP Control & Hydraulic & Hydraulic & MUX & MUX & MUX & MUX \\
\hline Mud Pump & $2 \times 1,600 \mathrm{hp}$ & $2 \times 1,600 \mathrm{hp}$ & $3 \times 1,600 \mathrm{hp}$ & $4 \times 2,200 \mathrm{hp}$ & $4 \times 2,200 \mathrm{hp}$ & Min $4 \times 2,200 \mathrm{hp}$ \\
\hline
\end{tabular}

類している。ジェネレーションの進化とともに稼働水深が 大きくなり, それに伴って掘削機器の能力・咒長性の強化, 搭載能力の大型化などが進んでいることが分かる。

\section{4. ジャッキアップリグの進化}

ジャッキアップリグについては, ジェネレーションとい う分類ではなく, Mat Cantilever/Slot, Standard, Premium, High Specification という 4 つのタイプに分類される。この タイプ分けについても統一的な定義はないが, 1958 年に 建造された白竜号から HAKURYU-11 まで JDC のジャッキ アップリグを，また High Specification には 2016 年にデリ バリーされた Maersk 社の Maersk Invincible を例に取りそ の分類を試みた（表 4)。日本で最初のリグである白竜号 の建造から約 60 年を経て, リグ船体の大型化，それに伴 う搭載能力の大容量化, 掘削機器の能力強化が進んでいる ことが確認できる。白竜号は建造後, アップグレード工事 を施し, 稼働水深の延伸や搭載機器の大型化はされてい るものの, その建造当時の仕様と HAKURYU-11 や Maersk Invincible と比較すると格段の技術的進歩を遂げており,
最大稼働水深, 最大掘削深度も大きく伸びていることが分 かる。

\section{5. 掘削リグの進化に寄与した要素技術}

掘削リグは, 機器の不具合によるダウンタイムを最小化 した連続稼働を実現するため, 機器を複数台装備するなど の冗長化の他, 機器整備要員の増強や整備しやすく安全性 を高める機器配置設計などが求められてきた。

掘削リグの進化は船体や掘削機器が大型化しただけでは なく, さまざまな要素技術の進歩があつた。主要な技術の 進化を見ていきたい。

\section{1 パワースイベル（トップドライブ）}

1970 年代に登場したパワースイベルは, 作井の歴史の 中においても大きな技術革新であつた。常時泥水循環, ド リルストリングの回転, 上げ下げが可能という, 作井技術 者にとっては夢のような機器であった。導入当初はトラブ ルが相次ぎ, 米国で初めて導入された際には相次ぐトラブ ルのため使用し続けることが断念された。しかし，第六白 竜の JDC クルーは，搭載された Bowen 社の ES-7 に発生 
表 4 ジャッキアップリグ タイプ別の比較

\begin{tabular}{|c|c|c|c|c|}
\hline リグ名 & $\begin{array}{c}\text { 白竜号 } \\
\text { （建造時） }\end{array}$ & $\begin{array}{l}\text { 第七白竜 } \\
\text { (建造時) } \\
\text { 現 SAGADRIL-2 }\end{array}$ & HAKURYU-11 & Maersk Invincible \\
\hline タイプ & Slot & Standard & Premium & High Specification \\
\hline 建造年月 & 1958 年 10 月 & 1981 年 3 月 & 2013 年 5 月 & 2016 年 11 月 \\
\hline 全長 / 全幅 / ハル深 & $61 \mathrm{~m} / 46 \mathrm{~m} / 6.1 \mathrm{~m}$ & $59 \mathrm{~m} / 56 \mathrm{~m} / 6.5 \mathrm{~m}$ & $75 \mathrm{~m} / 66.4 \mathrm{~m} / 7.7 \mathrm{~m}$ & $102.5 \mathrm{~m} / 88.8 \mathrm{~m} / 12 \mathrm{~m}$ \\
\hline $\begin{array}{l}\text { Variable Deck Load } \\
\text { (Drilling) }\end{array}$ & 1,300 tons & 2,200 tons & 3,350 tons & $\begin{array}{l}\text { Approx. 11,000 tons } \\
\text { including hook load }\end{array}$ \\
\hline 最大稼働水深 & $20 \mathrm{~m}$ & $76 \mathrm{~m}$ & $129.5 \mathrm{~m}$ & $150 \mathrm{~m}$ \\
\hline 最大掘削深度 & $1,524 \mathrm{~m}$ & $6,000 \mathrm{~m}$ & $10,668 \mathrm{~m}$ & $12,000 \mathrm{~m}$ \\
\hline 最大搭載人員数 & 57 名 & 91 名 & 150 名 & 180 名 \\
\hline デリック & 840 kips & 1,333 kips & 2,000 kips & 2,100 kips \\
\hline ドローワークス & 米国 UNI 社 U15 & $\begin{array}{c}\text { NATIONAL- 新潟 } \\
\text { 1320-UE }\end{array}$ & $\begin{array}{c}\text { NOV / ADS-10Q } \\
4,600 \mathrm{HP}\end{array}$ & $\begin{array}{c}\text { NOV SSGD } \\
5,750 \mathrm{HP}\end{array}$ \\
\hline マッドポンプ & 大原 $\mathrm{OH}-500 \times 2$ 台 & 12-P-160 × 2 台 & $14-\mathrm{P}-220 \times 3$ 台 & $14-\mathrm{P}-220 \times 4$ 台 \\
\hline
\end{tabular}

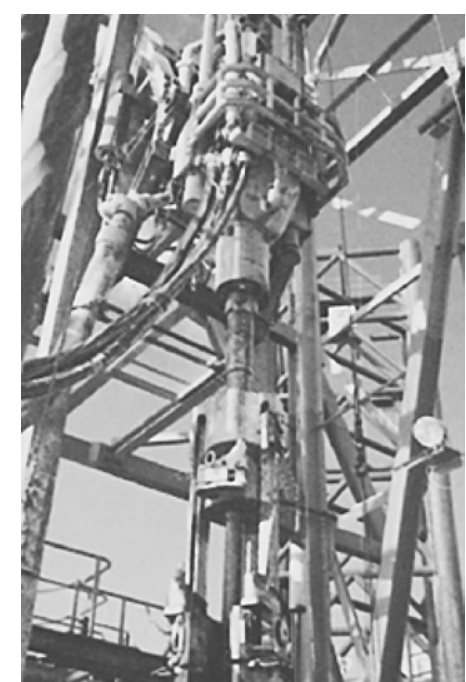

図 9 第六白竜に設置された Bowen 社のパワースイベル

出所：日本海洋掘削株式会社

表 5 初代パワースイベルと最新型トップドライブの比較

\begin{tabular}{|l|c|c|}
\hline & Bowen ES-7 & TDS-1500 \\
\hline 開発年 & 1970 年代 & 2014 \\
\hline 重 量 & $18,500 \mathrm{lbs}$ & $132,000 \mathrm{lbs}$ \\
\hline Torque & $30,000 \mathrm{ft}-1 \mathrm{bs}$ & $105,000 \mathrm{ft}-\mathrm{lbs}$ \\
\hline Load Rating & $500 \mathrm{tons}$ & $1,500 \mathrm{tons}$ \\
\hline Pressure Rating & $4,000 \mathrm{psi}$ & $20,000 \mathrm{psi}$ \\
\hline
\end{tabular}

する種々のトラブルを克服し，世界で初めて効果的な使用 方法の確立に成功した（図 9)。その卓越したパワースイ ベルの効果を見学するために，欧米諸国のコントラクター のエンジニアが第六白竜に乗船した記録も多数残されてお り，当時の注目度がうかがい知れる。

その後瞬く間に世界中のリグに搭載され，現在ではトッ プドライブとして NOV 社，Cameron 社，MHWirth 社な どが製作を手掛けているが，Bowen 社の ES-7 と 2014 年に 開発された NOV 社の最新モデルを比較すると（表 5)，そ の容量や寸法の進化が見て取れる。トップドライブの出現
はその後の傾斜掘りの技術進歩にも大きく貢献し, 掘削作 業そのものの時間短縮も実現した。

\subsection{BOP Control System}

浮遊式掘削リグの BOP のコントロールは，陸上坑井や ジャッキアップリグでも使用されているハイドロリック方 式からスタートした。しかしながら, 稼働水深が $600 \mathrm{~m}$ を 越えてくると課題が頻出してきた。水圧によりコントロー ルホースがつぶされる, コントロールホースと作動液の摩 擦が増加する, 深海の水温が低く作動液が固くなる, など の問題である。これらの課題を克服するために, Multiplex Control（以下, MUX Control）と呼ばれる方式が採用され る。本方式は，ハイドロリック方式では水深とともに増加 する信号伝達時間を水深に関係なくほぼゼロにすることを 可能にする。逆に問題点は，コストが高いことやシステム の十分なメンテナンスが必要となることである。本方式の 開発により, 大水深域においても BOP の迅速な作動が可 能となった。また MUX Controlの進化により, リグが位 置保持機能を喪失した際, 操作 1 つでライザーパイプのエ マージェンシーディスコネクトが可能となり，またリグと BOP 間の交信が途絶えた際には自動的にディスコネクト できるようになるなど，さまざまなセイフティバックアッ プ機能を保持できるようになつた。

\subsection{Heave-Compensation System}

浮遊式の海洋掘削リグは風や波浪による動摇が避けられ ない。この動摇は大きく分けると，横方向の摇れ（ローリ ング), 縦方向の摇れ (ピッチング), 上下動（ヒービング） の 3 つになる。横・縦方向の動摇については, BOP 装置 上部のフレックスジョイントおよびドリルパイプ自体の弾 性変形によってある程度吸収可能であるが, 船体のヒー ビングは, 掘削作業や BOP 降下作業, ケーシング降下作 業などに大きな影響を与える。この船体のヒービングを緩 衝し, 作業を円滑に行うために, 浮体式のドリルシップや セミサブリグにはヒーブコンペンセータが搭載されている。

これは浮遊式リグの初期の頃, 例えば第二白竜には搭載 されておらず, ドリルストリング編成内に組み込まれたバ 


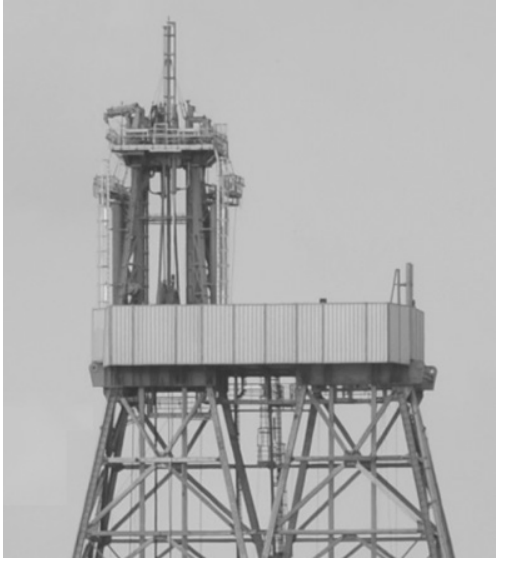

図 10 クラウンマウントコンペンセータ

出所 : ETESCO Takatsugu J

ンパーサブで船体のヒービングを緩衝していた。1970 年 代初頭になるとヒーブコンペンセータが採用されるように なる。JDCでは 1974 年完成の第三白竜からドリルストリ ングコンペンセータ（以下，DSC）がトラベリングブロッ クの下に取り付けられ，油圧と空気圧による緩衝作用を利 用して船体のヒービングを吸収した。その後第三白竜は, 波長の長い太平洋でも極めて高い稼働率を示すこととなる。

その後リグの大水深化，大型化に伴い，より重量の重い ストリングに対処するため, デリックのトップにコンペン セートする機能を持ったクラウンマウントコンペンセータ (以下, CMC) が登場し, 大水深対応リグに搭載されていっ た（図 10）。インライン型の DSC と比較して大容量のハ ンドリングが可能となり，アクティブコントロールによ り荷重変動が 5 〜 $10 \%$ たたものが $5 \%$ 以内に向上した。 また Open Hole Drilling の際に，ドリルストリングやケー

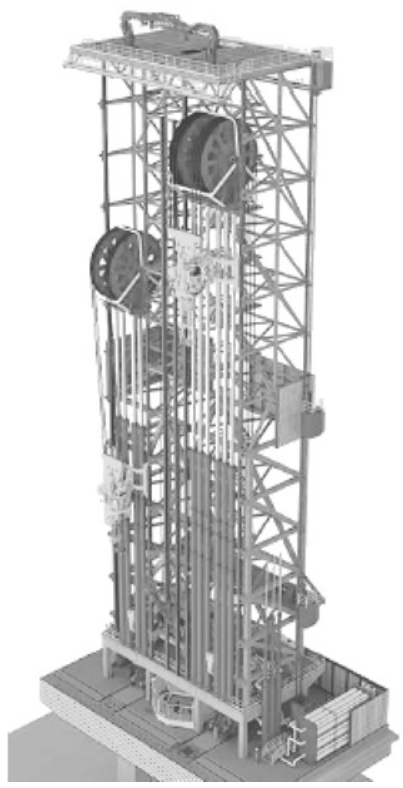

図 11 シリンダーリグ 出所 : MHWirth 社
シングを坑井に挿入する作業や, BOP のウェルヘッド上 への設置を安定して行うことが可能となった。

1990 年代になるとドローワークスにコンペンセート機 能を搭載した Active Heave Drawworks（以下，AHD）が登 場する。船体のヒービングを相殺する方向にドローワーク スのドラムを回転させることによりヒーブコンペンセータ の役割を果たしている。CMCの場合，容量が大きくなれ ば必然的に重量も大きくトップヘビーになり, 船体の重心 も上がってしまう。またデリックトップに位置することか ら, メンテナンスのためのアクセスにも課題がある。現在 でも $\mathrm{CMC}$ は新造リグに搭載されているが， $\mathrm{AHD}$ を採用 するリグも増加傾向にある。

ヒーブコンペンセータ機能を装備したリグとして， シ リンダータイプのリグも 1990 年に登場する（図 11）。ド ローワークスでブロックを上げ下げするのではなく，大型 のシリンダーによりドリルストリングを上下する。シリン ダーはドリルフロアより下に位置し, ヒーブコンペンセー 夕機能もあり $\mathrm{CMC}$ も不要なため船体の重心を低くできる メリットがある。ドローワークスのワイヤの Slip \& Cut の 手間も省け, また油圧駆動のため HPU は大型になるがて 長性に優れ, メンテナンス性もよいとされ, 実績として 20 基程の大水深リグが採用している。

\section{4 造船所の建造能力}

掘削リグの進歩は掘削機器の進歩だけではない。その搭 載を可能とした大型の掘削リグがあり, その掘削リグを建 造できるだけの造船所の設備や人材があるからこそ誕生し たとも言える。1970 年代に始まった掘削リグの第 1 次建 造ブームの際には, 1980 年代を中心に日本が掘削リグを 含む大規模海洋構造物の建造で世界をリードし, 100 基以 上の掘削リグが建造された。その後, 為替環境の変化や石 油価格の低迷に伴う採算の悪化により多くの造船会社が大 規模海洋構造物の建造から撤退した。2000 年代に入って からは第 2 次掘削リグ建造ブームを迎えたが, 日本国内の 造船所は大型化する掘削リグのプロジェクトには対応でき なくなっており, 代わって台頭したのが, 韓国やシンガポー ル, 中国の造船所であつた。各国とも大型の海洋プロジェ クトや掘削リグの建造に対応するべく設備の増強に力を入 れてきた。特に韓国での実績が多いドリルシップの建造 においては, 一般商船の建造と同様に, 装備された大型ク レーンが超大型ブロックをドック内に搬入し, ドック内で 一挙に接合することにより工期を短縮する工法が取られて いる。造船所が大型化する掘削リグの建造に対応可能と なつたことが，掘削リグの進化にも大きく寄与してきたと 考えられる。

\section{6. 未来リグ}

6.1 「無人化」と「特化型」

未来のリグを考える上で，「無人化」と「特化型」の 2 つのキーワードを用意した。遠い未来を予測する場合と, 現在の市場環境から現実的なところを考える。

まず遠い未来を見た場合には，リグは自動運転，すなわ 
ち「無人化」というステージを目指すと考える。もちろん 複雑な事象が絡み合う海洋掘削リグの運転は，操船や掘削 作業も含め「無人化」は簡単なものではないが，方向とし ては搭乗人員をできるだけ削減する方向に進むと予測する。

もう 1 つは「特化型」リグの需要増である。大きな流れ の中で未来を見た場合にはリグは一段と進化していくと考 えられるが，当面のマーケット状況を見ると，オペレータ やコントラクターが最新鋭の大型リグを新造することは考 えられず，コストでシェール開発や陸上掘削に打ち勝って いくには掘削するロケーションやドリリングプログラムに 合ったリグを改造か新造をして動員するというのがこれか らの流れと予測する。

\section{2 自動運転}

まず「無人化」に向かうという流れの中で，導入される 技術として考えられるのは掘削リグの自動運転である。自 動車の自動運転は技術的に可能なレベルとなり，各所に取 り付けられた多くのセンサーからもたらされるデー夕を基 に自動で運転がなされている。掘削リグも同様に，坑内で あればデー夕はこれまで泥水の中を通すパルスによって伝 達されていたが, ドリルパイプの中にワイヤーケーブルを 通すことにより大容量のデータがリグと坑内で送受信可能 となった。Managed Pressure Drilling も坑内の圧力をコン トロールする上で自動運転に寄与する技術だと思われる。 また坑内だけでなく, リグの各所に取り付けられたセン サーからも種々の情報が集積されることで, 坑内およびリ グの情報を一元化し，自動で掘削が可能となる。ドリリン グプログラムを最初に入力すれば，後は自動で坑井掘削が 可能となることも夢ではない。実用化に向けてメーカーも 実験的な試みを本格化させている。

\section{3 予知保全}

一方，メンテナンスについては，経験者の勘などに頼ら ず機器の保全ができる「予知保全」に向かおうとしている。 現在のリグでのメンテナンスの取り組み状況を見ると，故 障の都度修理や部品を交換する「事後対応」か，利用経験 や実績に基づき部品ごとに耐用年数を定め，定期的に点検 や修繥をする Time Base/Calendar Base とも呼ばれる「時 間基準保全」が行われている。後者の課題としては設定さ れた期間中に故障を起こしてしまうと事後対応になってし まうこと，また状態が良くても期日が来れば交換しなけれ ばならないという無駄が発生することであった。

この問題に対して，センサー技術や情報技術の進歩によ り，「状態基準保全」と呼ばれる保全方法の導入が始まっ ている。主に運転中の機器の異常の兆候を読夕取ることで, 計画的に処置をするという保全方法である。機器に取り付 けたセンサーからのデータが，実績や分析に基づき設定さ れたしきい值を超えた際に部品を取り替えることで，継続 して使用可能な部品を取り替えることが不要になり，コス ト面でのメリットが生まれる。

さらに, 将来の予測も加えた保全方法が「予知保全」で ある。現状把握だけではなく，人の経験や勘では対応しき れない複雑な事象も解析可能であり，センサーからの膨大
なデータをシステムが集積して, 分析し, 現状把握した上 で, 将来起こり得る事象を予測し, 推奨されるアクション を我々に提示する。こうした「状態基準保全」や「予知保 全」は, クルーによる定期検査や常時見て回ることの縮減 を可能とする。

\section{4 特化型}

大きな流れの中で未来を見た場合にはリグは一段と進化 していくと考えられるが，当面のマーケット状況を踏まえ 近い将来を考えた際には，多機能な設備を備えたリグでは なく，稼働するロケーションやドリリングプログラムに あったリグということになり，できるだけその掘削要求に 特化しコストを抑えたリグの需要が増えると予測し，「特 化型」を未来リグの 1 つとした。

特に最近は, 掘削契約の締結から操業開始までの期間が 短期間となる傾向にある中で，顧客要求に合わせるため， 迅速に改造工事を実施して操業に向かうという機動性が求 められる。

JDC の例だが，今夏 HAKURYU-5 がサハリンで稼働する ことになり，40 年以上の船齢を重ねたリグでも迅速にサ ハリン向けに改造工事を施し, 稼働地に向かえたという機 動性は，常日頃の整備を意らず， Ready to go, Ready to drill という状態を維持してきたクルーとそれを支える本社技術 陣の意識の高さ・技術力の高さが生かされたものであった。

新しいことだけが未来ではなく, 現状のリグを顧客要求 に合わせて操業するという「特化型」が当面のトレンドに

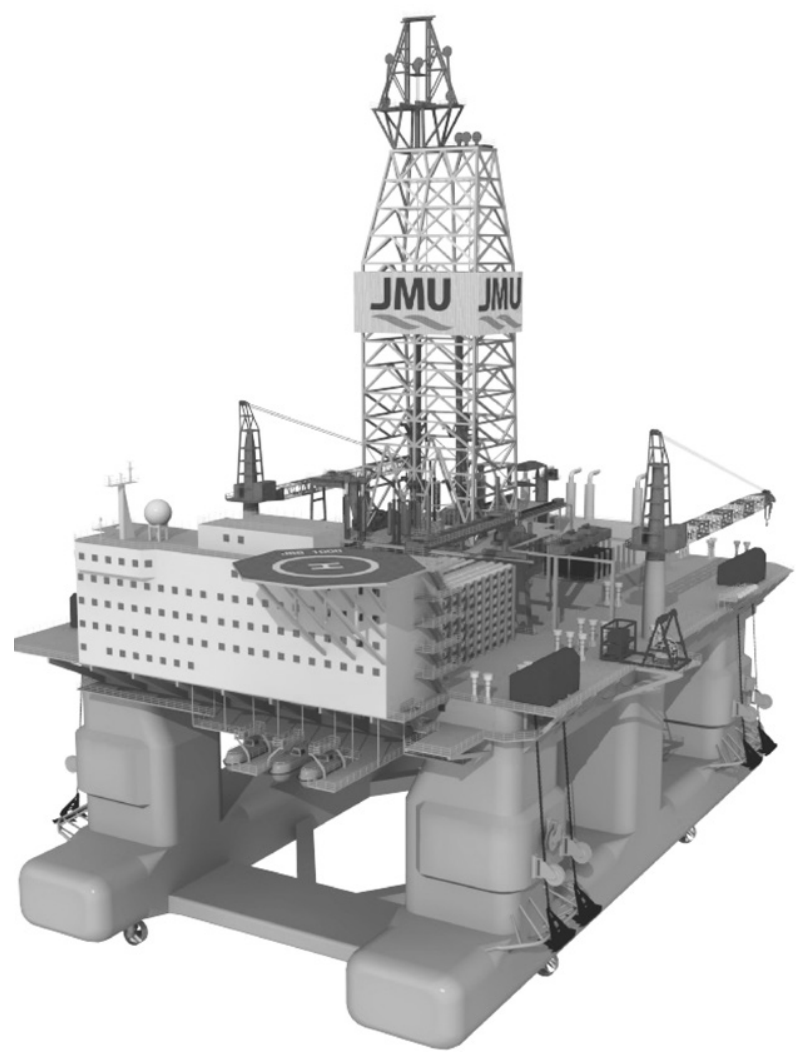

図 12 新セミサブ開発研究 出所 : ジャパンマリンユナイテッド社 
なると考える。

6.5 新セミサブ研究・開発

掘削リグの未来を見てきたが，JDCが現在まで培ってき たセミサブリグ操業のノウハウを継承するために準備をし ているプロジェクトを最後に紹介する。JDC は 2012 年か ら 2015 年まで, 造船所であるジャパンマリンユナイテッ ド株式会社と株式会社 IHI 社の 3 社で，新セミサブリグの 共同開発を実施した。また本研究開発は, 国土交通省の「海 洋資源開発技術開発支援事業」の支援対象事業として採択 されている。

本セミサブは「無人化」という未来まで見ているもので はないが，マーケットにおいて求められる，掘削技術の進 歩や規制動向に対応した最新掘削装置のための「プラット フォーム」となる。セミサブリグのデザインは搭載能力・ 復原性能・全体強度・全体配置・安全性などのバランスを 取るのが難しく，デザインスパイラルを回しながら最適解 にアプローチすることが求められる。そのため設計の段階 では，大型の船体とデッキスペースを準備し，顧客要求に 合わせてデザインをカスタマイズさせるという「特化型」 のコンセプトを準備している。技術動向を監視しつつ, 近 い将来石油価格が回復した時点で市場の期待に応えられ るよう, さらなるコスト低減を含め検討を継続中である(図 12)。

\section{7. ま と め}

栈橋から始まつた海洋掘削は，現在まで多くの困難と課 題に直面してきた。その課題克服のために発展してきた要 素技術があり，またその技術をリグ上という過酷な現場 で，実用化に至るまで奮闘し挑戦を繰り返すことで，さら なる沖合，大水深，大深度というフロンティアを開拓して きた先覚者たちがいた。石油開発業界を取り巻く環境が厳 しい中ではあるが，先覚者たちが作り上げてきた歴史の延 長線上にいることを誇りに思い，より安全で効率よく作業 ができる掘削リグを追求し，岸からは遠く離れた海洋での 操業で培ってきた技術を次の世代にも継承していくことこ そ我々の使命と感じ，結語としたい。

\begin{tabular}{llll} 
& \multicolumn{3}{c}{ SI 単位換算係数 } \\
$\mathrm{ft}$ & $\times 3.048^{*} \mathrm{E}-01=\mathrm{m}$ \\
$\mathrm{psi}$ & $\times 6.894757 \mathrm{E}+03=\mathrm{Pa}$ \\
kips & $\times 4.5454 \mathrm{E}+02=\mathrm{kg}$
\end{tabular}

US short ton $\times 9.071847 \quad \mathrm{E}+02=\mathrm{kg}$

参 考 文 献

新田純朗・大門勝悦・谷口典孝, 1981 ：パワースイベルの 実績について，石技誌，46(5)，327-333.

河内紀雄, 1983 : 海洋掘削装置発展の歴史, 石技誌, 48 (5) , 378-384.

日本海洋掘削株式会社, 1983 : 和して拓く $-J D C 15$ 年の 歩み。

林 廣一, 1988 : 第一白竜の海洋掘削における歴史的意義 の考察，石技誌，53(4)，274-282.

古谷 昭人, 1995: 大水深掘削の技術課題と展望，石技誌， 60 (5), 340-348.

横倉浩三，野中 朗，高田光芳， 1998 : 大水深掘削リグの 最新動向 大水深用掘削装置の技術革新および DPS のク ラスと信頼性の向上ならびに大水深掘削リグの最新建造 事例，石技誌，63(5)，376-387.

石黒 裕康，2003：2003 年大水深掘削リグの最新動向 大 水深石油開発ブーム, その後の動向, 石技誌, 68(5), 389-396

Drilling Contractor, 2005 : Rowan Companies marks $50^{\text {th }}$ anniversary of landmark LeTourneau jackup.

F.Jay Schempf, 2007 : Pioneering Offshore: The Early Years, Offshore Energy Center.

Mark J. Kaiser, Brian Snyder, Allan G. Pulsipher, 2013 : Bureau of Ocean Energy Management, Offshore Drilling Industry and Rig Construction Market in the Gulf of Mexico.

Transocean, 2013 : What is a " $7^{\text {th }}$ Generation" Ultra-deepwater Drillship?, http://www.aade.org/app/download/7236992560/AADE+DETG+10-17-2013+Andrew+Rennie+-+Transocean.pdf (cited 2014/12/8). 